DOI: $10.1515 / \mathrm{rpp}-2017-0022$

Senior Lecturer, YULIIA ZAKHARCHENKO

Dnipro State Agrarian and Economic University

Address: 25 Serhiy Yefremov St., Dnipro, 49027, Ukraine

E-mail: zacharchenko@list.ru

\title{
PROFESSIONAL TRAINING OF MARKETING SPECIALISTS: FOREIGN EXPERIENCE
}

\begin{abstract}
Due to content-based analysis of marketing specialists' professional training and approaches to development of their educational trajectory, it has been revealed that curricula and their content are given much attention by employers whose demands are focused on meeting current labour market conditions. It has been justified that despite the existing differences various approaches to forming future specialists' educational trajectory have one thing in common, i.e., an undeniable connection with employers' demands. The employers' impact is found at such stages as forming the content of curricula (particular disciplines) and monitoring quality of graduate knowledge gained in higher education institutions. This approach creates certain advantages as for quality performance of universities, correspondence of their curricula with relevant requirements of the labour market. However, most employers usually have little interest in predicting strategic development of the market. It has been proved that content saturation of curricula ensuring adjustment to current labour market conditions concurrently suppresses specialists' rapid adaptation to different scenarios of the future. Special attention has been paid to expediency of specialists' generalized training that provides them with some autonomy needed to implement their professional competences in the course of further development of the labour market.
\end{abstract}

Keywords: foreign experience, professional training, the USA, Germany, Great Britain, France, marketing specialist.

\section{INTRODUCTION}

The main long-term goal of Ukraine's development is creation of a modern innovative economy integrated into the global economy. Consequently, universities are to prepare highly qualified and competitive marketing specialists.

Goods and service marketing ensures the most optimal path to a final consumer. In general, it reduces unproductive waste of time and material that improves statistical indicators of Ukrainian economic sectors. Taking into account current shifting in future marketing specialists' training determined by a training period, the structure of curriculum content is an important aspect of providing competency-based features that correspond with labour market conditions. An excessive focus on correspondence with current requirements of employers may lead to potential incorrespondence with future scenarios of development.

Thus, development of goods and service markets is influenced and formed by several powerful players, who are responsible for strategic planning and create certain scenarios of the development. Such brands as Apple, Google, Tesla, Microsoft, Amazon and others strategically plan their own activities and are among the largest employers in the world. However, even the representatives of these companies being specialists in certain sectors are unable to accurately predict the specific conditions of market functioning in the future. That is practically the only possible trend forecasting containing only generalized 
criteria and characteristics, which are not enough to form a particular content saturation of curricula designed for future marketing specialists.

In Ukraine, one can obtain a degree in Marketing in 117 higher education institutions (VUZy Ukrainy, 2016). So, it is necessary to study foreign experience of tertiary education organization to further improve the education process at native universities.

\section{THE AIM OF THE STUDY}

Studying organizational principles of future marketing specialists' training at universities of leading countries, content saturation of curricula aimed at providing professional competences and ensuring correspondence with labour market requirements specify the main aim of providing future marketing specialists with education services.

\section{THEORETICAL FRAMEWORK AND RESEARCH METHODS}

Theoretical framework of the current research is based on experience of foreign countries in organization of professional training of future marketing specialists. In our opinion, such leading European countries as Germany, Great Britain, France and, in addition, the United States of America have accumulated the most relevant experience in the matter. To solve the aim set we have used analysis of research findings available to study the problem of marketing specialists' professional training, synthesis and generalization - to compare theoretical data and consequently determine the conditions of future marketing specialists' professional training. In such a way, we have been able to present our own conclusions as for general features of professional training of marketing specialists overseas and provided our own recommendations to enhance the efficiency of professional training of marketing specialists at native higher education institutons.

\section{RESULTS}

Analysis of such a global socioeconomic phenomenon as modern marketing, on the one hand, and the current state of pedagogical science and practice, on the other hand, shows that today many studies have been conducted that reveal these or other aspects of marketing specialists' professional training. Thus, we should highlight a fundamental development and an encyclopedic description of marketing theory and practice (A. Braverman, Ye. Holubkov, Ph. Kotler, J.-J. Lambin et al.), in the field of marketing specialists' professional training (S. Samarina, B. Soloviev et al.) and methodology of marketing research organization (H. Churchill, Ye. Holubkov, Ph. Kotler, E. Popov et al.).

In this context, M. Vachevskyi, V. Madzihon \& N. Prymachenko (2011) believe that international experience proves the possibility of significant economic changes due to development of marketing in human activities involving production and services. The very transformation of the marketing system has resulted in "economic miracle" that radically changed economic as well as living conditions in many countries (the USA, Japan, Korea, etc.) (p. 83).

Now, we would like to apply to the experience of certain higher education institutions. In the USA, the determining factor in professional training is the employer. Higher education institutions play a supporting role, flexibly responding to the economic situation. Every five years, training courses and programmes are reviewed by independent commissions of experts. There is exchange of experience of curriculum development among researchers, instructors and employers. Of great importance is provision of necessary resources, including modern equipment, which greatly contributes to the reputation of higher education that is always supported by the scholars conducting worldclass researches. 
Completed higher education in the USA is two-stage: the first degree (4 years) is completed with a Bachelors degree, the second one - a Masters degree. The second stage takes 1-2 years, but typically after two years of practical experience (Kitayeva, Gazizov, Zhuravlev, 2012).

In Germany, the main principle of higher education is academic freedom, i.e., a system that allows any student to determine the list of subjects they are interested in which subsequently will be included in their diploma (applicable to both undergraduate and postgraduate studies). The higher education system in Germany also combines the education process and research activities. These peculiarities determine the schedule of the education process within universities, namely, each semester consists of lecture periods (14-20 weeks) and self-regulated learning that suggests students being engaged in independent research (Bender, 1997; Longmuss, 1997; Verein Deutscher Ingenieure, 1995).

The standard model of professional training in Germany developed in cooperation with social partners is based on the main kinds of labour operations or activities according to a profession and contains a description of qualifications. A more detailed characteristic of necessary competences for each profession is presented in syllabi and programme specifications that include those subjects to be studied as well as schedules. There is also clear guidance on examination requirements. The main advantage of the professional model is a holistic approach and quite a high level of the competence obtained. This model includes basic as well as specialized technical knowledge (Poltavtseva, 2004).

The education content in Great Britain is determined by the employers' needs. Universities themselves decide on the education content and are responsible for it. Methodical supervision and programme specifications can vary at different universities. However, there is a general system of external ratings of teaching quality.

In Great Britain, qualifications refer to a document certifying development of specific competences required to perform any activity and certain standards as well.

Standards are the norms, which determine the level of quality or attainments, are based on competences and indicate what should be achieved in terms of implementing certain activities. In this respect, standards define the education process and assess the attainments. The qualification reflects competences, standards, the education process and assessment (Kotler \& Fox, 2011).

French higher education consists of three cycles. The first (two-year) cycle leads to a general university studies diploma (diplôme d'études universitaires générales - DEUG). It must be noted that graduates are entitled to specialization and may obtain a special diploma that greatly increases their employment opportunities. The second cycle (two-year) allows graduates to obtain a Masters degree, and after the first year - a "licence". Higher education is considered to be completed after the third cycle - a Licentiate degree (1 year) or $\mathrm{PhD}$ ( 3 years with obtaining an intermediate diploma in humanities after the first year).

In France, there are certain admission requirements to applicants which are divided into four phases: firstly, the enterprises' need for the specialist; secondly, the guaranteed application of the specialist's knowledge that virtually provides them with employment after graduation; thirdly, "know-how", i.e., the very system of training designed to meet the needs of enterprises-customers; fourthly, choosing a higher education institution that ensures the programme's implementation (Poltavtseva, 2004).

The programmes as well as approaches to the training profiles are reviewed every five years. It affects a contingent of students and the diploma content, too. 
Despite the existing differences, these various approaches to forming future specialists' educational trajectory have one thing in common, i.e., an undeniable connection with employers' demands. The employers' impact is found at such stages as forming the content of curricula (particular disciplines) and monitoring quality of graduate knowledge gained in higher education institutions. This approach creates certain advantages as for quality performance of universities, correspondence of their curricula with relevant requirements of the labour market. However, most employers usually have little interest in predicting strategic development of the market.

Only large companies that occupy a significant market share and, according to the Boston Consulting Group, are the most innovative, such as Apple, Google, Tesla, Microsoft, Amazon and others, invest in researches on future market and actively form it. The employers' requirements are accorded with modern age. Thus, the content saturation of curricula ensuring adjustment to current labour market conditions concurrently suppresses specialists' rapid adaptation to different scenarios of the future. In this regard, it is advisable to shift the learning objectives to ensure a high degree of university graduates' compliance with the current requirements to generalized skills and competences within professional expertise. The latter ensures autonomous or semi-autonomous development of existing and acquisition of new competences through self-development and self-regulated learning.

It should be noted that this approach bears some risk for graduates because of increasing time to adapt to the requirements and conditions where professional knowledge and skills are to be realized. In addition, providing knowledge and competences exceeding the minimum necessary level reduces education services market due to filling the labour market with specialists who engage in self-regulated learning and develop themselves. This is not a very attractive scenario for education institutions. Moreover, the process of selfregulated learning does not guarantee high quality of learning outcomes and their compliance with the expectations of both employers and graduates, whereas universities regulate the education process and have access to generalized data.

\section{CONCLUSIONS}

Today, many foreign universities and business schools offer quality education services in marketing. In terms of a wide choice of curricula, a future marketing specialist should pay special attention to the prestige of an institution, experience and professionalism of teaching staff.

Foreign universities offer curricula that are regulated by the state and public organizations as well as employers and meet their requirements.

The content of higher education is closely connected with the latest scientific and practical achievements and responds to the changes taking place. However, excessive correspondence of education services with the relevant requirements of employers may limit rapid adaptation to new scenarios of the future market. Shifting emphasis on providing a more generalized competence within a professional field allows future specialists to rapidly response to new challenges.

Determining the content of generalized training within marketing specialists' professional expertise, approaches and principles of its development is undoubtedly a necessary step towards forming students' educational trajectory. Ensuring an appropriate balance between compliance with the employers' requirements and the marketing specialist's ability to rapidly adapt to certain scenarios of evolution of the labour market, goods and services makes the market system whose active participants are marketing 
specialists rather flexible. The presence of additional situational flexibility provides an opportunity for more rapid development of the entire economic system, thus ensuring compliance with the needs and desires of final consumers, which eventually leads to the growth of social standards.

Rather perspective we see development of the methodology aimed at forming research competencies of future marketing specialists.

\section{REFERENCES}

1. Bender, B. (1997). Intergrierte Ingenieur-ausbildung-Praktiche Umsetzung an der TU-Berlin. In Melezinek, A. (Ed.) Ingenieur 2000: overinformed - undereducated? Referate des 26. Internationalen Symposiums "Ingenieurpadgogik" 97” (Vol. 37, pp. 149-154). Klagenfurt: Lenchtturm.

2. Chukhrai, N. (2009). Marketynhovi kompetentnosti i problemy pidhotovky fakhivtsiv z marketynhu. Markenynh v Ukraini, 2, 53-58.

3. Kashlacheva, T. S. (2007). Yevropeyskoe kachestvo vysshego obrazovaniya: kak my ponimaem ego. Sotsialno-gumanitarnye znaniya, 4, 167-177.

4. Kitayeva, L. A., Gazizov, M. B., Zhuravlev, B. L. (2012). Peredovoy zarubezhnyi opyt professionalnoy podgotovki kadrov. Vestnik Kazanskogo tekhnologicheskogo universiteta, 5, 241-248.

5. Kotler, Ph., \& Fox, K. (2011). Stratehichnyi matketynh dlia navchalnykh zakladiv. Kyiv: Ukrainska asotsiatsiia marketynhu.

6. Longmuss, J. (1997). Grundlagen einer Intepgrierten Ingenieurausbildung. In A. Melezinek (Ed.) Ingenieur 2000: overinformed - undereducated? Referate des 26. Internationalen Symposiums "Ingenieurpadgogik" 97” (Vol. 37, pp. 171-176). Klagenfurt: Lenchtturm.

7. Poltavtseva, E. S. (2004). Sravnitelno-pedagogicheskiy analiz razvitiya evropeyskikh sistem professionalnogo obrazovaniya. (Dys. kand. Ped. nauk). Severokazkazskiy gosudarstvennyi tekhnicheskiy universitet, Stavropol.

8. Verein Deutscher Ingenieure. (1995). Indenitrausbildung im Umbruch. Empfehlung des VDI fuer eine zukunftsorientierte Ingenierqualifikation. Duesseldorf: VDI.

9. Vachevskyi, M. V., Madzihon, V. M., \& Prymachenko, N. M. (2011). Promyslovyi marketynh. Formuvannia profesiinykh kompetentsii u maibutnikh marketolohiv. Kyiv: Kondor.

10. Vuzy Ukrainy. (2016). Spetsialnost "Marketing". Vzyato s https://ru.osvita.ua/ vnz/guide/search-17-0-0-87-117-100.html. 